Brit. J. industr. Med., 1965, 22, 121.

\title{
CHANGES IN VENTILATORY CAPACITY IN A GROUP OF FLAX WORKERS IN NORTHERN IRELAND
}

\author{
BY \\ G. C. R. CAREY and J. D. MERRETT \\ From the Department of Social and Preventive Medicine, \\ The Queen's University of Belfast
}

(RECEIVED FOR PUBLICATION AUGUST 27, 1964)

\begin{abstract}
One-second forced expiratory volume (F.E.V.1.0 $)$ and forced vital capacity (F.V.C.) were measured before starting work in five flax hacklers with symptoms of grade II byssinosis and in five matched controls. Similar measurements were taken in each group at the end of the day shift.

A significant $(P<0.05)$ decline in F.E.V.1.0 was observed in the hacklers during the day on Monday, Tuesday, Wednesday, and Friday. The F.V.C. also declined significantly in the hacklers on Monday, Tuesday, and Wednesday. In the control group, ventilatory function tended to decline during the day, but this was significant only for F.E.V..$_{\cdot 1 \cdot 0}$ on Monday. The reason for this is discussed.

Variations in the dust concentrations in the mill and in outdoor air pollution are shown to be unlikely to have affected the findings.

Morning values of F.E.V $\cdot \cdot_{1 \cdot 0}$ and of F.V.C. were consistently lower in the byssinotic group than in the matched controls, suggesting that the inhalation of flax dust causes not only daily variations in lung function but longer-term impairment of ventilatory capacity as well. Additional evidence is given for this conclusion from two other studies.
\end{abstract}

In a previous paper (Elwood, Pemberton, Merrett, Carey, and McAulay, 1965) an account was given of the occurrence of byssinosis in Northern Ireland flax workers.

McKerrow, McDermott, Gilson, and Schilling (1958) showed that the ventilatory capacity of byssinotic cardroom workers exposed to cotton dust declined significantly during the day. Mair, Smith, Wilson, and Lockhart (1960) found that the forced expiratory volume of byssinotic flax workers declined significantly on Mondays. Similar findings were reported by Bouhuys, Van Duyn, and Van Lennep (1961) in a study of flax byssinosis in the Netherlands.

It has been shown (Carey, Merrett, Elwood, Pemberton, and McAulay, 1965) that the mean forced expiratory volume in one second (F.E.V.1.0) and forced vital capacity (F.V.C.) of flax preparers measured on Tuesdays, Wednesdays or Thursdays is lower than that of non-byssinotic non-preparers, when factors of sex, age, stem height, smoking habits, location of mill (town or country), and type of fibre handled are held constant.

The diagnosis of flax byssinosis is made on a history of respiratory symptoms after exposure to flax dust on Mondays, and on other days of the week in more advanced cases. It is therefore important to know whether these periodic respiratory symptoms are accompanied by ventilatory impairment. The following experiment was designed to investigate this question.

\section{Methods}

Five male hacklers in a country mill, who were known to have grade II byssinosis, ${ }^{*}$ were matched as closely as possible with five controls from the same mill for age, sex, stem height, and smoking habits. The controls were a fitter, three joiners, and a bricklayer, none of whom had ever had symptoms of byssinosis. During the week of the experiment the controls were excluded from even occasional exposure to flax dust in the preparing rooms. In four out of the five pairs of workers the control smoked a

*Evidence of breathlessness or chest tightness or discomfort of the chest on every Monday and also on some other days, provided that 121 
similar, or greater, amount than the byssinotic. In the fifth pair the control smoked on average $8 \mathrm{~g}$. and the byssinotic $10 \mathrm{~g}$. of tobacco daily, a difference unlikely to be important.

The F.E.V $\cdot \cdot_{1 \cdot 0}$ and F.V.C. of each of the men were measured between 7.45 a.m. and 8.15 a.m. before they began work and again between 4.30 p.m. and 5.00 p.m. on each of the five days, Monday to Friday inclusive. A Poulton spirometer was used (McKerrow, McDermott, and Gilson, 1960), all measurements being taken by the same observer with the subject seated. All 10 subjects were experienced in these lung function tests as they had all participated in the main survey of ventilatory capacity (Carey $e t$ al., 1965). The mean of the first three technically satisfactory tests was taken as the appropriate measurement. Volumes were corrected for temperature but not for barometric pressure. All tests on the hacklers were carried out at the same place in the hackling room, and the tests of the controls in a room situated some distance from the dusty part of the mill.

Measurements of total and of respirable dust (less than 7 microns diameter) were taken at the same point in the centre of the hackling room at least five times during each day of the experiment. The methods used for the collection and analysis of the dust were those described by McAulay, Carey, Merrett, Elwood, and Pemberton (to be published).

Twenty-four-hour volumetric samples of outdoor air were taken in the precincts of the mill on each day of the experiment. The apparatus and methods of sampling and analysis of smoke and sulphur dioxide were those described by the Department of Scientific and Industrial Research (1957).

\section{Results}

Table 1 shows the morning and afternoon values of F.E.V. $\cdot_{\cdot 1 \cdot 0}$ and of F.V.C. for the five byssinotic workers and their matched controls for each day of the experiment.

Forced Expiratory Volume-one second.-Table 2 shows the analysis of variance of the data on F.E.V.1.0. The two component sums of squares

TABLE 1

MORNING AND AFTERNOON MEASUREMENTS OF F.E.V.1.0 AND F.V.C. IN FIVE MEN WITH BYSSINOSIS AND IN FIVE MATCHED CONTROLS

\begin{tabular}{|c|c|c|c|c|c|c|c|c|c|c|c|c|c|c|c|c|c|c|c|c|c|c|c|c|}
\hline \multirow{3}{*}{$\begin{array}{c}\text { Serial } \\
\text { No. of } \\
\text { Worker }\end{array}$} & \multirow{3}{*}{ Group } & \multirow{3}{*}{$\begin{array}{l}\text { Age } \\
\text { (yr.) }\end{array}$} & \multirow{3}{*}{$\begin{array}{l}\text { Stem } \\
\text { Hght. } \\
\text { (cm.) }\end{array}$} & \multirow{3}{*}{$\begin{array}{c}\text { To- } \\
\text { bacco } \\
\text { g./day }\end{array}$} & \multicolumn{10}{|c|}{ F.E.V.1.0 (litres) } & \multicolumn{10}{|c|}{ F.V.C. (litres) } \\
\hline & & & & & \multicolumn{2}{|c|}{ Monday } & \multicolumn{2}{|c|}{ Tuesday } & \multicolumn{2}{|c|}{ Wed. } & \multicolumn{2}{|c|}{ Thurs. } & \multicolumn{2}{|c|}{ Friday } & \multicolumn{2}{|c|}{ Monday } & \multicolumn{2}{|c|}{$\overline{\text { Tuesday }}$} & \multicolumn{2}{|c|}{ Wed. } & \multicolumn{2}{|c|}{ Thurs. } & \multicolumn{2}{|c|}{ Friday } \\
\hline & & & & & a.m. & p.m. & a.m. & p.m. & a.m. & p.m. & a.m. & p.m. & a.m. & p.m. & a.m. & p.m. & a.m. & p.m. & a.m. & p.m. & a.m. & p.m. & a.m. & p.m \\
\hline $\begin{array}{l}14 / 7 \\
14 / 81 \\
14 / 60 \\
14 / 75 \\
14 / 70 \\
14 / 49 \\
14 / 63 \\
14 / 83 \\
14 / 5 \\
14 / 43\end{array}$ & $\begin{array}{l}\mathbf{B} \\
\mathbf{C} \\
\mathbf{B} \\
\mathbf{C} \\
\mathbf{B} \\
\mathbf{C} \\
\mathbf{B} \\
\mathbf{C} \\
\mathbf{B} \\
\mathbf{C}\end{array}$ & $\begin{array}{l}63 \\
64 \\
54 \\
54 \\
45 \\
44 \\
49 \\
43 \\
52 \\
48\end{array}$ & $\begin{array}{l}87 \\
83 \\
84 \\
86 \\
93 \\
91 \\
81 \\
85 \\
89 \\
89\end{array}$ & $\begin{array}{r}10 \\
10 \\
10 \\
8 \\
10 \\
20 \\
6 \\
15 \\
12 \\
18\end{array}$ & $\begin{array}{l}1.8 \\
1.5 \\
2.1 \\
2.7 \\
2.0 \\
2.7 \\
1.8 \\
3.0 \\
2.4 \\
2.2\end{array}$ & $\begin{array}{l}0.9 \\
1.3 \\
1.7 \\
2.1 \\
1.9 \\
2.4 \\
1.6 \\
2.7 \\
1.7 \\
2.0\end{array}$ & $\begin{array}{l}1.5 \\
1.2 \\
1.9 \\
2.1 \\
2.1 \\
2.5 \\
1.8 \\
2.8 \\
2.2 \\
2.0\end{array}$ & \begin{tabular}{l|}
1.2 \\
1.4 \\
1.1 \\
1.9 \\
2.0 \\
2.3 \\
1.5 \\
2.7 \\
1.6 \\
2.1
\end{tabular} & $\begin{array}{l}1.7 \\
1.2 \\
1.9 \\
2.5 \\
2.3 \\
2.5 \\
2.3 \\
3.0 \\
2.2 \\
2.1\end{array}$ & $\begin{array}{l}1.4 \\
1.4 \\
1.2 \\
2.1 \\
2.1 \\
2.4 \\
1.7 \\
2.9 \\
1.8 \\
2.1\end{array}$ & $\begin{array}{l}1.6 \\
1.1 \\
1.7 \\
2.2 \\
2.2 \\
2.4 \\
2.0 \\
2.8 \\
2.3 \\
2.1\end{array}$ & $\begin{array}{l}1.6 \\
1.4 \\
1.5 \\
1.6 \\
2.4 \\
2.4 \\
1.8 \\
2.9 \\
1.7 \\
2.0\end{array}$ & $\begin{array}{l}1.8 \\
1.3 \\
1.9 \\
2.5 \\
2.4 \\
2.7 \\
2.0 \\
2.8 \\
2.2 \\
2.1\end{array}$ & $\begin{array}{l}1.6 \\
1.2 \\
1.6 \\
2.0 \\
2.4 \\
2.1 \\
1.7 \\
2.9 \\
1.7 \\
2.1\end{array}$ & $\begin{array}{l}2.7 \\
2.7 \\
3.8 \\
3.4 \\
2.9 \\
3.6 \\
3.2 \\
3.6 \\
3.2 \\
3.6\end{array}$ & $\begin{array}{l}1.7 \\
2.7 \\
3.1 \\
3.2 \\
2.9 \\
3.4 \\
2.8 \\
3.5 \\
2.2 \\
2.8\end{array}$ & $\begin{array}{l}2.2 \\
2.7 \\
3 \cdot 5 \\
3 \cdot 1 \\
3 \cdot 2 \\
3.9 \\
3.0 \\
3.6 \\
3.4 \\
2.9\end{array}$ & $\begin{array}{l}2.1 \\
3.0 \\
2.3 \\
3.3 \\
3.1 \\
3.6 \\
2.8 \\
3.6 \\
2.2 \\
2.9\end{array}$ & $\begin{array}{l}2.5 \\
2.9 \\
3.4 \\
3.2 \\
3.6 \\
3.9 \\
3.0 \\
3.7 \\
3.4 \\
3.5\end{array}$ & $\begin{array}{l}2.4 \\
3 \cdot 1 \\
2.4 \\
3.4 \\
3.4 \\
3 \cdot 9 \\
2.7 \\
3 \cdot 7 \\
2.2 \\
3.0\end{array}$ & $\begin{array}{l}2.4 \\
2.8 \\
3.6 \\
3.3 \\
3.6 \\
3.9 \\
2.9 \\
3.6 \\
3.4 \\
3.0\end{array}$ & $\begin{array}{l}2.2 \\
2.9 \\
3.4 \\
3.2 \\
3.8 \\
3.8 \\
2.8 \\
3.6 \\
2.6 \\
2.5\end{array}$ & $\begin{array}{l}2 \cdot 5 \\
2 \cdot 8 \\
3 \cdot 8 \\
3 \cdot 2 \\
3 \cdot 6 \\
4 \cdot 2 \\
3 \cdot 1 \\
3 \cdot 6 \\
3 \cdot 3 \\
3 \cdot 4\end{array}$ & \begin{tabular}{|l}
2.3 \\
2.8 \\
3.3 \\
2.9 \\
$4 \cdot 0$ \\
3.8 \\
2.8 \\
$3 \cdot 8$ \\
3.0 \\
3.1
\end{tabular} \\
\hline
\end{tabular}

$\mathbf{B}=$ byssinotic; $\mathbf{C}=$ control.

TABLE 2

ANALYSIS OF VARIANCE OF F.E.V.1.0 READINGS IN TABLE 1

\begin{tabular}{|c|c|c|c|c|}
\hline Source of Variation & $\begin{array}{l}\text { Sum of Squares } \\
\left(\text { (litres }^{2}\right)\end{array}$ & D.F. & $\begin{array}{c}\text { Mean Square } \\
\left.\text { (litres }{ }^{2}\right)\end{array}$ & Variance Ratio \\
\hline $\begin{array}{l}\text { Between subjects: } \\
\text { Between groups (G) } \\
\text { Error (a) }\end{array}$ & $\begin{array}{r}2 \cdot 8561 \\
15 \cdot 7668\end{array}$ & $\begin{array}{l}1 \\
8\end{array}$ & $\begin{array}{l}2 \cdot 8561 \\
1 \cdot 9709\end{array}$ & $\mathrm{~F}=1.45, \mathrm{n}_{1}=1, \mathrm{n}_{2}=8, \mathrm{P}>0.20$ \\
\hline $\begin{array}{l}\text { Within subjects: } \\
\text { Between days (D) } \\
D \times G \\
\text { Error (b) }\end{array}$ & $\begin{array}{l}0 \cdot 3194 \\
0 \cdot 2454 \\
0 \cdot 7672\end{array}$ & $\begin{array}{r}4 \\
4 \\
32\end{array}$ & $\begin{array}{l}0.0799 \\
0.0614 \\
0.0240\end{array}$ & $\begin{array}{l}\mathrm{F}=3.33, \mathrm{n}_{1}=4, \mathrm{n}_{2}=32,0.05>P 0.01 \\
\mathrm{~F}=2.56, \mathrm{n}_{1}=4, \mathrm{n}_{2}=32,0.10>\mathrm{P}>0.05\end{array}$ \\
\hline $\begin{array}{l}\text { Between times }(T) \\
T \times G \\
T \times \mathbf{D} \\
T \times G \times D \\
\text { Error (c) }\end{array}$ & $\begin{array}{l}1 \cdot 5129 \\
0 \cdot 2601 \\
0 \cdot 1986 \\
0 \cdot 1214 \\
1 \cdot 3420\end{array}$ & $\begin{array}{r}1 \\
1 \\
4 \\
4 \\
40\end{array}$ & $\begin{array}{l}1.5129 \\
0.2601 \\
0.0497 \\
0.0304 \\
0.0336\end{array}$ & $\begin{array}{ll}\mathbf{F}=45.03, & \mathrm{n}_{1}=1, \mathrm{n}_{2}=40, \mathrm{P}<0.001 \\
\mathrm{~F}=7.74, & \mathrm{n}_{1}=1, \mathrm{n}_{2}=40, \mathrm{P}<0.001 \\
\mathrm{~F}=1.48, & \mathrm{n}_{1}=4, \mathrm{n}_{2}=40, \mathrm{P}>0.20 \\
\mathrm{~F}<1, & \mathrm{n}_{1}=4, \mathrm{n}_{2}=40, \mathrm{P}>0.20\end{array}$ \\
\hline Total & $23 \cdot 3899$ & 99 & & \\
\hline
\end{tabular}


TABLE 3

COMPARISON OF AVERAGE F.E.V.1.0 BETWEEN TIMES AND BETWEEN DAYS IN FIVE BYSSINOTICS AND FIVE CONTROLS (LITRES)

\begin{tabular}{|c|c|c|c|c|c|c|c|}
\hline \multirow{2}{*}{ Group } & \multirow{2}{*}{ Time } & \multicolumn{6}{|c|}{ Day } \\
\hline & & Monday & Tuesday & Wednesday & Thursday & Friday & All Days \\
\hline Byssinotics & $\begin{array}{l}\text { Morning (M) } \\
\text { Afternoon (A) } \\
\text { Difference (M-A) } \\
t\end{array}$ & $\begin{array}{l}2 \cdot 02 \\
1.56 \\
0.46 \\
3 \cdot 97^{*}\end{array}$ & $\begin{array}{l}1.90 \\
1.48 \\
0.42 \\
3.62^{*}\end{array}$ & $\begin{array}{l}2 \cdot 08 \\
1.64 \\
0 \cdot 44 \\
3 \cdot 80^{*}\end{array}$ & $\begin{array}{l}1.96 \\
1 \cdot 80 \\
0 \cdot 16 \\
1 \cdot 38\end{array}$ & $\begin{array}{l}2 \cdot 06 \\
1 \cdot 80 \\
0 \cdot 26 \\
2 \cdot 24^{*}\end{array}$ & $\begin{array}{l}2 \cdot 00 \\
1.66 \\
0 \cdot 34 \\
6 \cdot 55^{*}\end{array}$ \\
\hline Controls & $\begin{array}{l}\text { Morning (M) } \\
\text { Afternoon (A) } \\
\text { Difference (M-A) } \\
\mathbf{t}\end{array}$ & $\begin{array}{l}2 \cdot 42 \\
2 \cdot 10 \\
0 \cdot 32 \\
2 \cdot 76^{*}\end{array}$ & $\begin{array}{l}2 \cdot 12 \\
2 \cdot 08 \\
0.04 \\
0.35\end{array}$ & $\begin{array}{l}2 \cdot 26 \\
2 \cdot 18 \\
0 \cdot 08 \\
0 \cdot 69\end{array}$ & $\begin{array}{l}2.12 \\
2.06 \\
0.06 \\
0.52\end{array}$ & $\begin{array}{l}2 \cdot 28 \\
2 \cdot 06 \\
0 \cdot 22 \\
1 \cdot 90\end{array}$ & $\begin{array}{l}2 \cdot 24 \\
2 \cdot 10 \\
0 \cdot 14 \\
2 \cdot 70^{*}\end{array}$ \\
\hline
\end{tabular}

* Significant at $\mathbf{P}<0.05$.

Standard error of difference between two time means for a given day and group = 0.1159.

Standard error of difference between two day means for a given time and group $=0 \cdot 1072$.

Standard error of difference between two time means (all days combined) for a given group $=0.0519$.

making up error $(a)$ were homogeneous $(\mathrm{F}=4 \cdot 70$, $\left.\mathrm{n}_{1}=4, \mathrm{n}_{2}=4,0 \cdot 10>\mathrm{P}>0.05\right)$, so they are combined to give the error variance in Table 2. The analysis shows significant* differences in average F.E.V.1.0 between days and between times of day, and further suggests that differences between times of day were not always consistent in each group of workers. Because of the significant interactions between groups and times of day, the F.E.V. $\cdot_{1 \cdot 0}$ readings were examined for each group separately by analysis of variance. These analyses confirmed the result of the analysis shown in Table 2 .

Table 3 shows that for both byssinotic and control groups, the average morning F.E.V.t.0 for all days combined was significantly greater than the average afternoon F.E.V.1.0. The average decline in the F.E.V. $\cdot_{1 \cdot 0}$ in the byssinotic group of 0.34 litre appears to be clinically important in that symptoms of dyspnoea were produced, but the decline of 0.14 litre in the control group is probably not so.

${ }^{*}$ The criterion of significance used throughout is $P<0.05$.
A comparison of the average morning and afternoon readings for each day separately showed that significant decreases occurred on four of the five days in the byssinotic group (Monday, Tuesday, Wednesday, and Friday) but only on Monday in the control group. Moreover, average F.E.V.1.0 readings were similar in the byssinotic, but not in the control group, on each of the five mornings. The difference between these readings in the control group was mainly due to a relatively high F.E.V .1.0 $_{1}$ on Monday. The average F.E.V.1.0 was similar on each afternoon in the control group, but significant differences occurred between those readings in the byssinotic group, mainly due to the fact that afternoon readings obtained on Monday and Tuesday were lower than those on Thursday and Friday.

Forced Vital Capacity.-Table 4 shows the analysis of variance of F.V.C. readings. The two sums of squares contributing to error (a) were homogeneous $\left(F=1 \cdot 16, n_{1}=4, n_{2}=4, P>0 \cdot 20\right)$,

TABLE 4

ANALYSIS OF VARIANCE OF F.V.C. READINGS IN TABLE 1

\begin{tabular}{|c|c|c|c|c|}
\hline Source of Variation & $\begin{array}{l}\text { Sum of Squares } \\
\left.\text { (litres })^{2}\right)\end{array}$ & D.F. & $\begin{array}{l}\text { Mean Square } \\
\left(\text { litres }^{2}\right)\end{array}$ & Variance Ratio \\
\hline $\begin{array}{l}\text { Between subjects: } \\
\text { Between groups (G) } \\
\text { Error (a) }\end{array}$ & $\begin{array}{r}3 \cdot 1684 \\
13 \cdot 6320\end{array}$ & $\begin{array}{l}1 \\
8\end{array}$ & $\begin{array}{l}3 \cdot 1684 \\
1 \cdot 7040\end{array}$ & $\mathrm{~F}=1 \cdot 86, \mathrm{n}_{1}=1, \mathrm{n}_{2}=8, \mathrm{P}>0 \cdot 20$ \\
\hline $\begin{array}{l}\text { Within subjects: } \\
\text { Between days (D) } \\
\text { D } \times \text { G } \\
\text { Error (b) }\end{array}$ & $\begin{array}{l}0 \cdot 7914 \\
0 \cdot 4646 \\
2 \cdot 0880\end{array}$ & $\begin{array}{r}4 \\
4 \\
32\end{array}$ & $\begin{array}{l}0 \cdot 1979 \\
0 \cdot 1162 \\
0 \cdot 0653\end{array}$ & $\begin{array}{l}F=3.03, n_{1}=4, n_{2}=32,0.05>P>0.01 \\
F=1.78, n_{1}=4, n_{2}=32,0.10>P>0.20\end{array}$ \\
\hline $\begin{array}{l}\text { Between times }(\mathbf{T}) \\
\mathbf{T} \times \mathbf{G} \\
\mathbf{T} \times \mathbf{D} \\
\mathbf{T} \times \mathbf{G} \times \mathbf{D} \\
\text { Error }(\mathrm{c})\end{array}$ & $\begin{array}{l}1 \cdot 6900 \\
0 \cdot 6084 \\
0 \cdot 2530 \\
0 \cdot 3246 \\
2 \cdot 5840\end{array}$ & $\begin{array}{r}1 \\
1 \\
4 \\
4 \\
40\end{array}$ & $\begin{array}{l}1.6900 \\
0.6084 \\
0.0633 \\
0.0812 \\
0.0646\end{array}$ & $\begin{array}{l}F=26 \cdot 16, n_{1}=1, n_{2}=40, P<0.001 \\
F=9 \cdot 42, n_{1}=1, n_{2}=40,0.01>P>0.001 \\
F=1, n_{1}=4, n_{2}=40, P>0.20 \\
F=1 \cdot 25, n_{1}=4, n_{2}=40, P>0.20\end{array}$ \\
\hline Total & $25 \cdot 6044$ & 99 & & \\
\hline
\end{tabular}


TABLE 5

COMPARISON OF AVERAGE F.V.C. BETWEEN TIMES AND BETWEEN DAYS IN FIVE BYSSINOTICS AND FIVE MATCHED CONTROLS (LITRES)

\begin{tabular}{|c|c|c|c|c|c|c|c|}
\hline \multirow{2}{*}{ Group } & \multirow{2}{*}{ Time } & \multicolumn{6}{|c|}{ Day } \\
\hline & & Monday & Tuesday & Wednesday & Thursday & Friday & All Days \\
\hline Byssinotics & $\begin{array}{l}\text { Morning (M) } \\
\text { Afternoon (A) } \\
\text { Difference (M-A) } \\
\text { t }\end{array}$ & $\begin{array}{l}3 \cdot 16 \\
2 \cdot 54 \\
0 \cdot 62 \\
3 \cdot 86^{*}\end{array}$ & $\begin{array}{l}3 \cdot 06 \\
2 \cdot 50 \\
0 \cdot 56 \\
3 \cdot 48^{*}\end{array}$ & $\begin{array}{l}3 \cdot 18 \\
2 \cdot 66 \\
0 \cdot 52 \\
3 \cdot 24^{*}\end{array}$ & $\begin{array}{l}3 \cdot 16 \\
2 \cdot 96 \\
0 \cdot 20 \\
1 \cdot 24\end{array}$ & $\begin{array}{l}3 \cdot 26 \\
3 \cdot 08 \\
0 \cdot 18 \\
1 \cdot 12\end{array}$ & $\begin{array}{l}3 \cdot 16 \\
2 \cdot 75 \\
0 \cdot 41 \\
5 \cdot 70^{*}\end{array}$ \\
\hline Controls & $\begin{array}{l}\text { Morning (M) } \\
\text { Afternoon (A) } \\
\text { Difference (M-A) } \\
\text { t }\end{array}$ & $\begin{array}{l}3 \cdot 38 \\
3 \cdot 12 \\
0 \cdot 26 \\
1 \cdot 61\end{array}$ & $\begin{array}{r}3.24 \\
3.28 \\
-0.04 \\
-0.25\end{array}$ & $\begin{array}{l}3.44 \\
3.42 \\
0.02 \\
0.12\end{array}$ & $\begin{array}{l}3 \cdot 32 \\
3 \cdot 20 \\
0 \cdot 12 \\
0 \cdot 75\end{array}$ & $\begin{array}{l}3 \cdot 44 \\
3 \cdot 28 \\
0 \cdot 16 \\
1 \cdot 00\end{array}$ & $\begin{array}{l}3 \cdot 36 \\
3 \cdot 26 \\
0 \cdot 10 \\
1 \cdot 39\end{array}$ \\
\hline
\end{tabular}

*Significant at $\mathbf{P}<0.05$.

Standard error of difference between two time means for a given day and group $=0 \cdot 1607$.

Standard error of difference between two day means for a given time and group $=0 \cdot 1612$.

Standard error of difference between two time means (all days combined) for a given group $=0.0719$.

so they are combined in Table 4. This analysis suggests that there were differences in the average F.V.C. between times of day and between days, but that the differences between times were not always consistent in each group.

Table 5 shows that in the byssinotic group, but not in the control group, the average morning F.V.C. for all days combined was significantly greater than the average afternoon reading. On each of the five days, the F.V.C. in the byssinotic group decreased on average from morning to afternoon, the differences being significant on Monday, Tuesday, and Wednesday. In the control group, the average F.V.C. decreased on four out of the five days, but none of these differences was significant. Within each of the two groups the average morning readings were similar on each day of the experiment, but there were differences in the average afternoon readings. In the byssinotic group these differences were largely due to lower readings on Monday and Tuesday than on Thursday and Friday. There was a non-consistent pattern in the afternoon readings of the control group, although the average F.V.C. on Monday afternoon was low compared with that on other afternoons.

An analysis of variance was again applied to the data for each group of workers separately because of the significant interaction between groups and times of day. These analyses confirmed the analysis shown in Table 4.

The figure summarizes in diagrammatic form the data relating to the daily changes in ventilatory capacity.

Longer-term Impairment of Lung Function.-In the analysis presented so far, all comparisons were made within groups of workers. Comparison between groups is also relevant. The error variances
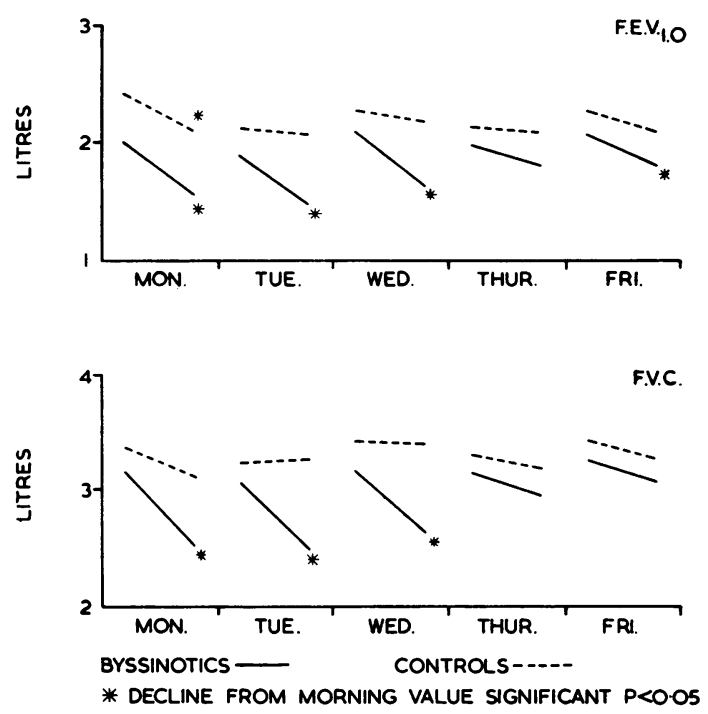

FIGURE.-Daily changes in the mean F.E.V.1.0 and F.V.C. of five hacklers with byssinosis and five controls.

obtained from the analysis of variance for each group were used to calculate the appropriate standard errors because of the significant interactions already reported. Further analysis showed that the average morning F.E.V $\cdot_{\cdot \cdot \cdot 0}$ and F.V.C. for all days combined were significantly lower in the byssinotic group than in the control group (Tables 3 and 5). The difference in average F.E.V $\cdot 1 \cdot 0$ was 0.24 litre $($ S.E. $=0.036)$ and in F.V.C. was 0.20 litre (S.E. $=0.045)$. Similar trends were observed when the average morning readings were compared between the two groups of workers for each day separately. The morning values of the byssinotic preparers for both F.E.V.1.0 and F.V.C. were consistently lower than the corresponding values for their matched controls. 
TABLE 6

DAILY VARIATION OF DUST LEVELS IN THE HACKLING ROOM DURING THE WEEK OF EXPERIMENT

\begin{tabular}{l|c|c|c|c|c}
\hline & \multicolumn{3}{|c|}{ Mean of the log. Dust Concentrations } \\
\cline { 2 - 5 } & Monday & Tuesday & Wednesday & \multicolumn{2}{|c}{ Thursday } \\
\hline Respirable dust & $1.94(5)$ & $2.03(6)$ & $1.97(7)$ & $1.92(6)$ & $1.94(6)$ \\
\hline Total dust & $2.27(6)$ & $2.37(6)$ & $2.06(7)$ & $2.24(7)$ & $2.32(6)$ \\
\hline
\end{tabular}

The number of observations on which each mean is based is given in parentheses.

Dust Concentrations and Air Pollution.-It is conceivable that the variations in the decline of lung function on different days in the byssinotic men might have been due to a variation in the concentration of flax dust in the mill and/or to variations in atmospheric pollution. To test these hypotheses, the measurements of dust concentration and air pollution, referred to earlier, were made each day.

The results for dust concentrations in the hackling room, expressed as log. $\mathrm{mg} . / 100 \mathrm{~m}^{3}$ of air, ${ }^{*}$ are shown in Table 6. Analyses of variance were carried out on these data to determine whether the log. concentration either of respirable or of total dust was similar on each day of the experiment. No significant differences were found for respirable dust $\left(\mathrm{F}<1, \mathrm{n}_{1}=4, \mathrm{n}_{2}=25, \mathrm{P}>0.20\right)$ or for total dust $\left(F=2.67, n_{1}=4, n_{2}=27,0.10>P>0.05\right)$. The daily average concentration of smoke was $6.2 \mathrm{mg}$./ $100 \mathrm{mi}^{3}$ of air with standard deviation 1.6 (range 4.0-8.0). Sulphur dioxide levels were zero on Monday, Tuesday, and Wednesday, and $\mathbf{0} \cdot 2$ part per million of air on the Thursday and Friday of the experiment.

It is improbable therefore that the variations in the daily patterns of decline in ventilatory capacity can be accounted for by variations in the dust levels or air pollution.

\section{Discussion}

Short-term Effect.-The study has shown that the average ventilatory capacity, as measured by the F.E.V.1.0 and F.V.C., of a group of male hacklers with grade II flax byssinosis declined significantly not only on Monday but also on Tuesday and Wednesday. Even on Thursday and Friday there was some fall, but this was significant only in the case of the F.E.V.1.0 on Friday. The results provide a physiological explanation of the sensation of oppression or tightness in the chest coming on towards the end of the day, particularly at the beginning of the week, complained of by the subjects of byssinosis. Similar findings in cotton cardroom workers

*The reasons why log. concentrations were used, and not actual units, are given elsewhere (McAulay et al., to be published). have been reported by McKerrow et al. (1958).

There was a tendency for the F.E.V.1.0 of the matched controls to fall slightly during each day, but only on the Monday was the average fall in this group significant. One man, a joiner (serial no. 14/75), was largely responsible for this significant fall. He later admitted to occasional tightness of the chest on breathing certain types of saw-dust and said that his chest had been tight on the Monday in question.

The cause of the daily decline in ventilatory capacity in byssinotic flax workers is presumed to be due to the formation in the lungs, as a response to the inhalation of flax dust, of a substance or substances causing smooth muscle contraction in the airways.

Davenport and Paton (1962) identified in cotton dust small amounts of histamine, a known smooth muscle contractor substance, 5-hydroxytryptamine, and an additional unknown contractor substance. Nicholls (1962) demonstrated the presence of smooth muscle contractor substance in extracts of cotton, flax, hemp, sisal, and jute in that order of activity. Davenport and Paton (1962) suggested that the improvement of symptoms in cotton byssinosis in the latter part of the week may be due to depletion in the tissues of the precursor to the smooth muscle contractor substances after exposure to the dust in the earlier part of the week. The week-end break may allow re-accumulation of precursor substance and therefore make possible the exacerbation of symptoms on Mondays.

Longer-term Effect.-The results presented also showed that the average morning values of F.E.V.1.0 and F.V.C. of the byssinotic subjects before starting work were significantly lower than those of the controls. This suggests a more permanent degree of impairment of lung function. Batawi, Schilling, Valić, and Walford (1964) reported lower mean values of indirect maximum breathing capacity in byssinotic cotton workers before starting the shift compared with non-byssinotic cotton workers, and considered this to be evidence of a longer-term effect. 
Further evidence of a longer-term effect on ventilatory capacity was obtained in another study which we carried out in which the F.E.V.1.0 and F.V.C. of all the men over the age of 50 in another country mill were measured on a Monday morning before the men started work. It was assumed that measurements of lung function made at this time, after the week-end break, would represent the subjects' normal lung function.

There were 23 men in the mill in this age group and they fell into three categories: A, seven men not exposed to flax dust and not having byssinosis; B, seven men exposed to flax dust and not having byssinosis; and $\mathrm{C}$, nine men exposed to flax dust and having byssinosis.

Table 7 shows the relevant measurements. The mean values for age and stem height did not differ significantly between the groups, and examination of the data does not suggest any preponderance of a combination of low stem height with greater age in any one group. The average tobacco consumption was lowest, and the proportion of non-smokers highest, in the byssinotic group. Any impairment of lung function due to current smoking habits would therefore have been less in the byssinotic than in the other groups.

The table shows that the mean F.E.V.1.0 and F.V.C. values of the byssinotic group, C, were sig- nificantly lower than those of the non-exposed nonbyssinotic group, A. They were also less, but not significantly less than those of group B, the exposed non-byssinotic group. The values of the exposed non-byssinotic group were lower than those of the non-exposed non-byssinotic group, but not significantly so.

The size of the differences in ventilatory capacity between the byssinotic and non-exposed nonbyssinotic groups of older men are clinically important and, if permanent, represent a serious degree of respiratory disability.

Elwood (1965), in a study of men who had retired from, or who had left, a flax spinning mill, found that those who had had byssinosis while at work complained at the time of interview of dyspnoea on exertion significantly more often than those who had not had byssinosis when working. This finding also indicates that permanent impairment of ventilatory capacity can occur in some cases of byssinosis.

Elwood et al. (1965) suggest that flax dust may have two effects on the lungs: (1) a temporary and specific effect, observable as Monday symptoms of chest discomfort; (2) a chronic non-specific effect, similar to that produced by other dusts or tobacco smoke, and predisposing to chronic bronchitis and dyspnoea on exertion in that both chronic bronchitis and dyspnoea on exertion were shown (Elwood et al.,

TABLE 7

F.E.V.1.0 AND F.V.C. IN THREE GROUPS OF MEN BEFORE STARTING WORK ON A MONDAY

\begin{tabular}{|c|c|c|c|c|c|c|c|}
\hline Group & $\begin{array}{c}\text { Serial } \\
\text { No. of } \\
\text { Worker }\end{array}$ & $\begin{array}{c}\text { Byssinosis } \\
\text { Grade }\end{array}$ & $\begin{array}{l}\text { Age } \\
\text { (yr.) }\end{array}$ & $\begin{array}{c}\text { Stem } \\
\text { Height } \\
(\mathrm{cm} .)\end{array}$ & $\begin{array}{c}\text { Tobacco } \\
\text { Consumption } \\
\text { (g./day) }\end{array}$ & $\underset{\text { (litres) }}{\text { F.E.V.1.0 }}$ & $\begin{array}{l}\text { F.V.C. } \\
\text { (litres) }\end{array}$ \\
\hline $\mathbf{A}$ & $\begin{array}{l}2 / 364 \\
2 / 400 \\
2 / 401 \\
2 / 315 \\
2 / 328 \\
2 / 402 \\
2 / 355\end{array}$ & $\begin{array}{l}\mathbf{0} \\
0 \\
0 \\
0 \\
0 \\
0 \\
0\end{array}$ & $\begin{array}{l}62 \\
55 \\
54 \\
52 \\
54 \\
50 \\
63\end{array}$ & $\begin{array}{l}90 \\
85 \\
85 \\
88 \\
90 \\
78 \\
92\end{array}$ & $\begin{array}{r}0 \\
0 \\
0 \\
21 \\
15 \\
15 \\
3\end{array}$ & $\begin{array}{l}2.8 \\
2.7 \\
3.5 \\
2.8 \\
2.8 \\
3.1 \\
3.4\end{array}$ & $\begin{array}{l}3.5 \\
4.2 \\
3.9 \\
4.0 \\
3.3 \\
3.9 \\
3.9\end{array}$ \\
\hline Mean & & & $55.7 \pm 1.94$ & $88 \pm 1.45$ & $7 \cdot 7$ & $3.01 \pm 0.12$ & $3.81 \pm 0.12$ \\
\hline B & $\begin{array}{l}2 / 267 \\
2 / 309 \\
2 / 258 \\
2 / 88 \\
2 / 301 \\
2 / 101 \\
2 / 262\end{array}$ & $\begin{array}{l}0 \\
0 \\
0 \\
0 \\
0 \\
0 \\
0\end{array}$ & $\begin{array}{l}56 \\
55 \\
60 \\
51 \\
59 \\
65 \\
50\end{array}$ & $\begin{array}{l}92 \\
83 \\
88 \\
84 \\
93 \\
89 \\
88\end{array}$ & $\begin{array}{r}10 \\
12 \\
14 \\
10 \\
0 \\
0 \\
22\end{array}$ & $\begin{array}{l}2.9 \\
1.7 \\
3.5 \\
1.7 \\
3.3 \\
1.5 \\
2.6\end{array}$ & $\begin{array}{l}3 \cdot 6 \\
2 \cdot 2 \\
4 \cdot 4 \\
4 \cdot 1 \\
4 \cdot 3 \\
4.0 \\
3 \cdot 2\end{array}$ \\
\hline Mean & & & $56.6 \pm 1.94$ & $88 \pm 1.45$ & $9 \cdot 7$ & $2.46 \pm 0.31$ & $3.69 \pm 0.29$ \\
\hline $\mathrm{C}$ & $\begin{array}{l}2 / 107 \\
2 / 307 \\
2 / 112 \\
2 / 95 \\
2 / 114 \\
2 / 113 \\
2 / 272 \\
2 / 96 \\
2 / 308\end{array}$ & $\begin{array}{l}\text { I } \\
\text { I } \\
\text { I } \\
\text { I } \\
\text { II } \\
\text { I } \\
\text { II } \\
\text { I } \\
\text { I }\end{array}$ & $\begin{array}{l}\mathbf{5 6} \\
53 \\
50 \\
67 \\
57 \\
50 \\
57 \\
59 \\
57 \\
\end{array}$ & $\begin{array}{l}85 \\
88 \\
84 \\
79 \\
85 \\
86 \\
88 \\
85 \\
90 \\
\end{array}$ & $\begin{array}{r}0 \\
0 \\
0 \\
0 \\
5 \\
10 \\
15 \\
0 \\
30 \\
\end{array}$ & $\begin{array}{l}2.5 \\
1.5 \\
2.2 \\
0.7 \\
2.6 \\
1.9 \\
2.0 \\
1.1 \\
3.2 \\
\end{array}$ & $\begin{array}{l}2.8 \\
2.4 \\
2.6 \\
2.0 \\
3.3 \\
3.4 \\
3.4 \\
3.6 \\
4.0 \\
\end{array}$ \\
\hline Mean & & & $56.2 \pm 1.71$ & $86 \pm 1 \cdot 28$ & 6.7 & $1.97 \pm 0.26$ & $3.06 \pm 0.21$ \\
\hline
\end{tabular}

$A=$ non-byssinotics not exposed to flax dust

The standard errors follow the \pm sign. 
$1965)$ to be significantly more common among flax preparers than among non-preparers.

The data shown here in Tables 3 and 5 provide objective evidence of the 'temporary and specific' effect of flax dust, and the data shown in Tables 3, 5 , and 7 also show that longer-term impairment of ventilatory function is present in byssinotic flax workers, which might be attributed to a 'chronic non-specific' effect of the dust.

This study formed part of a survey of byssinosis in flax workers undertaken at the request of the Northern Ireland Ministry of Labour and National Insurance, which made a grant towards the cost.

It could not have been carried out without the wholehearted co-operation of the management of the mills concerned. We are grateful to them and to the workers who volunteered for participation in the study.

We also wish to thank Professor J. Pemberton and Professor E. A. Cheeseman for their advice, Mr. R. H.
McClarin, who carried out the dust and air pollution measurements, and Miss J. Broderick, Mrs. E. E. Kingston, and Miss S. J. Smith, who helped in the preparation of the report.

\section{REFERENCES}

Batawi, M. A. El, Schilling, R. S. F., Valić, F., and Walford, J. (1964). Brit. J. industr. Med., 21, 13.

Bouhuys, A., Van Duyn, J., and Van Lennep, H. J. (1961). Arch. environm. Hlth, 3, 499.

Carey, G. C. R., Merrett, J. D., Elwood, P. C.. Pemberton, J., and McAulay, I. R. (1965). Brit.J. industr. Med., 22, 190.

Davenport, A., and Paton, W. D. (1962). Ibid., 19, 19.

Department of Scientific and Industrial Research (1957). The Measurement of Air Pollution. H.M.S.O., London.

Elwood, P. C. (1965). Brit. J. industr. Med., 22, 38 Pemberton, J., Merrett, J. D., Carey, G. C. R., and McAulay, I. R. (1965). Ibid., 22, 27.

McAulay, I. R., Carey, G. C. R., Merrett, J. D., Elwood, P. C., and Pemberton, J. (to be published).

McKerrow, C. B., McDermott, M., and Gilson, J. C. (1960). Lancet,

$-\frac{1,149 .}{15,75 .}$, and Schilling, R. S. F. (1958). Brit. J. industr. Med., Mair, A, Smith, D. H., Wilson, W. A., and Lockhart, W. (1960). Nicholls, P. J. (1962). Ibid., 19, 33. 